\title{
PRAWO ALIMENTACYJNE JAKO PRZYKŁAD REGULACJI PRAWNEJ SOLIDARNOŚCI MIĘDZYPOKOLENIOWEJ
}

\section{UWAGI OGÓLNE}

Decyzją Parlamentu Europejskiego i Rady nr 940/2011/UE z 14 września 2011 r. ustanowiono rok 2012 Rokiem Aktywności Osób Starszych i Solidarności Międzypokoleniowej ${ }^{1}$. W dokumencie tym zwrócono uwagę, że w Europie wzrasta liczba osób w wieku około 60 lat i starszych, co stanowi „niewątpliwe wyzwanie dla całego społeczeństwa i dla wszystkich pokoleń w Europie”. Wskazano ponadto, że jest to również problem związany z pojęciem solidarności międzypokoleniowej oraz kwestia dotycząca rodziny. Dalsza część Decyzji poświęcona została przede wszystkim podkreśleniu znaczenia aktywizacji osób starszych w zakresie życia zawodowego i społecznego, a także podniesienia poziomu zdrowia i warunków życia tej grupy społeczeństwa. Wydaje się jednak, że problematykę solidarności międzypokoleniowej rozpatrywać można w zdecydowanie szerszym kontekście.

Warto na wstępie ustalić, co ukrywa się pod pojęciem solidarności międzypokoleniowej, i wskazać, w jakim ujęciu będzie ono analizowane w niniejszym opracowaniu. Solidarność definiuje się jako „poczucie wspólnoty i współodpowiedzialności wynikające ze zgodności poglądów oraz dążeń" oraz jako „odpowiedzialność zbiorową i indywidualną określonej grupy osób za całość wspólnego zobowiązania”2. Natomiast pokolenie to - z jednej strony - ,grupa ludzi będących mniej więcej w tym samym wieku”, z drugiej - „,członkowie jakiejś rodziny, będący w podobnym wieku i zajmujący $\mathrm{w}$ niej taka sama pozycję" ${ }^{3}$. O solidarności międzypokoleniowej możemy zatem mówić w wymiarze publicznym, społecznym - będzie się ona wyrażała na przykład w gotowości ponoszenie kosztów do budżetu państwa przez wszystkich członków społeczeństwa w celu stworzenia środków na świadczenia wypłacane ze strony państwa. Solidarność międzypokoleniowa może jednak przybierać także postać solidarności rodzinnej, o charakterze prywatnym, w której pokolenie w wieku produkcyjnym zapewnia środki utrzymania następnym pokoleniom i udziela

${ }^{1}$ Decyzja Parlamentu Europejskiego i Rady nr 940/2011/UE z 14 września 2011 r. w sprawie Europejskiego Roku Aktywności Osób Starszych i Solidarności Międzypokoleniowej (2012), Dz. Urz. UE z 23 września 2011 r., nr L 246, s. 5 i n., http://eur-lex.europa.eu/LexUriServ/LexUriServ.do? uri =OJ:L:2011:246:0005:0010:PL:PDF (22.03.2012).

${ }^{2}$ Zob. http://sjp.pwn.pl/szukaj/solidarność (22.03.2012).

${ }^{3}$ Zob. http://sjp.pwn.pl/szukaj/pokolenie (22.03.2012). 
wsparcia pokoleniu starszemu, korzystając także z jego doświadczenia i pomocy. Przyglądając się różnym modelom rozwiązań, można wskazać, że rozbudowanym systemem świadczeń ze strony państwa charakteryzuja się prawodawstwa skandynawskie, natomiast silne poczucie solidarności rodzinnej występuje w krajach śródziemnomorskich.

Analiza dokumentów wydanych przez Parlament Europejski i Komisję w kontekście problemów demograficznych w Europie oraz w związku z ogłoszeniem Roku Aktywności Osób Starszych i Solidarności Międzypokoleniowej prowadzi do wniosku, że poczucie solidarności międzypokoleniowej rozumiane jest raczej jako stwarzanie przez państwo odpowiednich warunków jak najdłuższej możliwości prowadzenia aktywnego życia zawodowego i społecznego przez osoby starsze, w celu zapewnienia im maksymalnej samowystarczalności ${ }^{4}$. W tym kontekście jako główne instrumenty promowania sprawiedliwości społecznej wskazuje się ,,system emerytalny, budżet, zadłużenie, opiekę zdrowotną i złożoną rehabilitację" 5 .

Szukając rozwiązań problemu demograficznego w Europie, zwraca się jednak także uwage na znaczenie rodziny w zakresie udzielania wsparcia międzypokoleniowego zarówno wobec dzieci, jak i osób niesamodzielnych, w tym osób starszych. Zauważa się w związku z tym potrzebę wprowadzenia odpowiedniej polityki godzenia życia zawodowego $\mathrm{z}$ rodzinnym. W tym kontekście między innymi ,,wzywa się państwa członkowskie do przyjęcia środków na rzecz uznania niewidzialnej i nieformalnej pracy - podejmowanej w zakresie solidarności międzypokoleniowej przez członków rodziny (głównie kobiety) w każdym wieku, polegającej na opiekowaniu się starszymi i młodszymi krewnymi wymagającymi opieki - na płaszczyźnie prawnej, społecznej i gospodarczej (w szczególności w zakresie zabezpieczenia społecznego, statusu zawodowego, zarobków i równych szans dla mężczyzn i kobiet)"6. Państwa członkowskie powinny także poszukiwać rozwiązań trudności, jakie napotykają tacy opiekunowie rodzinni, związanych z prawem swobodnego wyboru podjęcia się tej funkcji, możliwością łączenia pracy zarobkowej ze sprawowaniem opieki oraz dostępem do systemów zabezpieczenia społecznego i emerytury, które pozwolą uniknąć zubożenia, wynikającego z decyzji o sprawowaniu opieki nad niesamodzielnym członkiem rodziny ${ }^{7}$.

Wskazano ponadto szczególną rolę osób starszych w rodzinie w zapewnianiu opieki nad małoletnimi dziećmi, podkreślając nie tylko społeczną, ale także ekonomiczną wartość ich zaangażowania w tym zakresie ${ }^{8}$.

Dostrzegając rolę rodziny we wzajemnym wspieraniu się pokoleń, zauważono jednak, że wraz z upływem czasu, przy kontynuacji obecnej sytuacji

\footnotetext{
${ }^{4}$ W ten sposób problem został ujęty w decyzji Parlamentu Europejskiego i Rady nr 940/2011/UE z 14 września 2011 r. w sprawie Europejskiego Roku Aktywności Osób Starszych i Solidarności Międzypokoleniowej.

5 Rezolucja Parlamentu Europejskiego z 11 listopada 2010 r. w sprawie wyzwań demograficznych i solidarności między pokoleniami (2010/2027(INI)), Dz. Urz. UE C (E), nr 74 z 13 marca 2012 r., s. 22, http://eur-lex.europa.eu/LexUriServ/LexUriServ.do?uri=OJ:C:2012:074E:0019:0034:PL:PDF (22.03.2012).

${ }^{6}$ Ibidem, s. 24.

7 Ibidem, s. 33.

8 Ibidem, s. 29.
} 
demograficznej w Europie, rodzinie coraz trudniej będzie samodzielnie zaspokajać potrzeby swoich członków. Stąd wzrastać w tym zakresie będzie rola pomocy socjalnej udzielanej przez państwo i społeczności lokalne ${ }^{9}$.

Niniejsze opracowanie ma na celu przyjrzenie się zagadnieniu solidarności międzypokoleniowej na gruncie polskiego prawa prywatnego. Szczególnym działem prawa zajmującym się tą tematyką jest prawo rodzinne, regulujące prawa i obowiązki osobiste oraz majątkowe między członkami rodziny. W Komunikacie Komisji Wspólnot Europejskich do Parlamentu Europejskiego, Rady, Europejskiego Komitetu Ekonomiczno-Społecznego i Komitetu Regionów na temat promowania solidarności międzypokoleniowej zwrócono uwagę, że $\mathrm{w}$ ramach polityki rodzinnej należy podjąć działania wywierające wpływ na sytuacje rodzin nie tylko $\mathrm{w}$ zakresie edukacji, polityki zatrudnienia, mieszkalnictwa czy polityki zdrowotnej, ale także w odniesieniu do określenia wzajemnych praw i obowiązków członków rodziny regulowanych przez prawo cywilne ${ }^{10}$.

W kontekście solidarności międzypokoleniowej na pierwszym planie pojawia się prawo alimentacyjne, jako najbardziej oczywista forma pomocy udzielanej sobie przez osoby spokrewnione. Nie można jednak nie zauważyć także ogólnego obowiązku wspierania się nałożonego na rodziców i dzieci we wzajemnych relacjach (art. 87 k.r.o.). Przepis ten w żaden sposób nie ogranicza wspomnianego obowiązku do relacji łączących rodziców z dzieckiem małoletnim, nie uzależnia też jego istnienia od wspólnego zamieszkiwania. Przyjąć zatem należy, że dotyczy on w ogóle rodziców i dzieci, a wynika z łączącego ich stosunku pokrewieństwa. Trwa w związku z tym przez całe ich życie, a sposób jego realizacji zależy od konkretnej sytuacji rodzinnej.

Rodzina, choć nie przysługuje jej podmiotowość prawna ${ }^{11}$, tworzy szczególnego rodzaju grupę osób fizycznych połączonych ze sobą takimi stosunkami rodzinnoprawnymi, jak: małżeństwo, pokrewieństwo, przysposobienie czy powinowactwo. Powstanie jednego rodzaju stosunku rodzinnoprawnego nie ogranicza się do wywołania skutków wyłącznie miedzy jego stronami, lecz rodzi konsekwencje także wobec innych osób. Zawarcie małżeństwa przez kobietę i mężczyznę powoduje równoczesne powstanie więzi powinowactwa między każdym z małżonków a rodziną drugiego. Urodzenie dziecka powoduje nie tylko powstanie więzi macierzyństwa, ale także ojcostwa, rodzeństwa oraz relacji prawnej między dziadkami a wnukami. Jedno zdarzenie wywołuje zatem jednoczesne powstanie kilku stosunków prawnych.

$\mathrm{Z}$ tak uregulowanych stosunków rodzinnoprawnych wynika szczególna odpowiedzialność członków rodziny za siebie nawzajem. Podkreślić w tym

\footnotetext{
${ }^{9}$ Komunikat Komisji Wspólnot Europejskich Zielona Księga „,Wobec zmian demograficznych: nowa solidarność między pokoleniami”, Bruksela, 16 marca 2005 r., http://eur-lex.europa.eu/LexUriServ/site/ pl/com/2005/com2005_0094pl01.pdf.

${ }^{10}$ Komunikat Komisji do Parlamentu Europejskiego, Rady, Europejskiego Komitetu Ekonomiczno-Społecznego i Komitetu Regionów - Promowanie solidarności między pokoleniami, http://eur-lex. europa.eu/LexUriServ/LexUriServ.do?uri = CELEX:52007DC0244:PL:NOT (22.03.2012).

${ }^{11}$ T. Smyczyński, O stosunku prawnym opartym na więzi rodzinnej, w: A. Choduń, S. Czepita (red.), W poszukiwaniu dobra wspólnego. Ksiega jubileuszowa Profesora Macieja Zielińskiego, Szczecin 2010, s. 704 .
} 
miejscu należy, że bardziej niż z prawem stanowionym łączy się ona z zasadami słuszności oraz poczuciem moralnego obowiązku wspierania swoich najbliższych ${ }^{12}$. Prawo sankcjonuje zatem jedynie pewne minimum uprawnień i obowiązków istniejących pomiędzy członkami rodziny, których dochodzić można w drodze przymusu państwowego. Bezwzględny charakter przepisów regulujących prawa i obowiązki wynikające ze stosunku alimentacyjnego oraz fakt, iż powstaje on ex lege, są wyrazem szczególnego znaczenia tej problematyki zarówno dla jednostek tworzących rodzinę, jak i dla całego społeczeństwa ${ }^{13}$. Obowiązek alimentacyjny wyprzedza bowiem obowiązek państwa polegajacy na udzielaniu pomocy społecznej, co jest wyrazem zasady pomocniczości państwa w tym zakresie ${ }^{14}$. W pierwszej kolejności zatem środków utrzymania powinni dostarczać sobie wzajemnie członkowie rodziny, a dopiero gdy nie sa oni w stanie podołać temu zadaniu albo gdy ich zabraknie, aktualizuje się rola państwa.

Solidarność międzypokoleniowa $\mathrm{w}$ zakresie prawa alimentacyjnego przejawia się $\mathrm{z}$ pewnością $\mathrm{w}$ odpowiednim uregulowaniu sposobu dostarczania środków utrzymania i wychowania pomiędzy rodzicami i dziećmi, ze szczególnym uwzględnieniem sytuacji dziecka małoletniego, jako istoty słabszej. Należy jednak zwrócić uwagę, że stosunek alimentacyjny istnieje $\mathrm{w}$ ogóle między krewnymi w linii prostej, łączy zatem także na przykład dziadków z wnukami. Co więcej, obowiązek alimentacyjny między osobami spokrewnionymi w linii prostej wyprzedza obowiązek krewnych z linii bocznej (art. 129 k.r.o.).

Prawo i obowiązek udzielania wsparcia materialnego występuja także w przypadku orzeczonego przez sąd przysposobienia, stosunku wzorowanego na pokrewieństwie. Pomiędzy adoptowanym dzieckiem a rodziną adoptującego powstaje, co do zasady, taka więź jak między tą rodziną a dzieckiem naturalnym osoby przysposabiającej. Dlatego też wszelkie uwagi dotyczące alimentacji pomiędzy zstępnymi i wstępnymi odnoszą się także do osób pozostających $\mathrm{w}$ stosunku przysposobienia. Wyjatkiem jest, orzekana niezwykle rzadko, adopcja niepełna, powodująca powstanie więzi wyłącznie pomiędzy przysposabianym i przysposabiajacym, lecz nieobejmujacca rodziny przysposabiającego i niewyłączająca relacji prawnej pomiędzy dzieckiem a jego rodziną pochodzenia (art. 124 k.r.o.). Ten rodzaj adopcji charakteryzuje się tym, że w miejsce rodziców dziecka wchodzi rodzic adopcyjny. Ma to swoje konsekwencje także w dziedzinie prawa alimentacyjnego, zgodnie z którym obowiązek

12 T. Smyczyński, w: idem (red.), System prawa prywatnego, t. 12: Prawo rodzinne $i$ opiekuńcze, Warszawa 2011, s. 754.

${ }^{13}$ M. Andrzejewski, w: H. Dolecki, T. Sokołowski (red.), Kodeks rodzinny i opiekuńczy. Komentarz, Warszawa 2010, s. 731.

${ }^{14}$ T. Smyczyński zwraca uwagę, że: „Subsydiarna funkcja świadczeń z zakresu pomocy społecznej wskazuje od razu na pierwszoplanową rolę obowiązków alimentacyjnych członków rodziny. Dopiero bowiem w wypadku, gdy osoby zobowiązane do alimentacji nie wypełniają tego obowiązku albo nie moga go spełnić, albo osoba w potrzebie nie ma w ogóle krewnych zobowiązanych do alimentacji ani własnych środków utrzymania, organ opieki społecznej może przyznać stosowne świadczenie" (idem, Alimentacja członków rodziny $w$ świetle systemu zabezpieczenia społecznego, Wrocław-Warszawa-Kraków-Łódź-Gdańsk 1989, s. 207-208). Zasadę pomocniczości państwa podkreśla także M. Andrzejewski, Prawo rodzinne i opiekuńcze, Warszawa 2010, s. 217. W ten sposób także wyrok SN z 3 września 1998 r., OSN Izba Cywilna 1999, nr 3, poz. 53. 
przysposabiającego wyprzedza wstępnych i rodzeństwo przysposobionego, a obowiązek adoptowanego dziecka wobec jego wstępnych i rodzeństwa obciąża go w ostatniej kolejności (art. $131 \S 1$ k.r.o.).

O więzi międzypokoleniowej można także mówić w odniesieniu do powinowactwa w linii prostej, a zatem relacji pomiędzy teściem/teściową a zięciem/synową oraz relacji pomiędzy ojczymem/macochą a pasierbem/pasierbica. Prawo alimentacyjne w ograniczonym zakresie uwzględnia ten stosunek rodzinnoprawny, jako źródło uprawnienia i obowiązku alimentacyjnego. Zgodnie z art. 144 k.r.o. środków utrzymania mogą domagać się we wzajemnych relacjach ojczym/macocha i pasierb/pasierbica. Ich uprawnienia alimentacyjne zależą jednak od tego, czy znajdują uzasadnienie w zasadach współżycia społecznego. Prawo domagania się świadczeń przez ojczyma lub macochę zależy ponadto także od tego, czy osoba ta łożyła wcześniej na utrzymanie dziecka swojego małżonka. W literaturze dominuje pogląd, że ojczym/macocha wchodza $\mathrm{w}$ relacji alimentacyjnej $\mathrm{w}$ miejsce rodzica, wyprzedzając krewnych dziecka, jeżeli przemawiają za tym względy słuszności ${ }^{15}$. Znaczenie alimentacji pomiędzy dzieckiem małżonka a małżonkiem rodzica wzrasta w dobie zwiększającej się liczby rozwodów i związanym z tym zjawiskiem tak zwanych rodzin rekonstruowanych, w których dzieci dorastaja wychowywane przez jednego $\mathrm{z}$ rodziców i jego małżonka ${ }^{16}$.

\section{ALIMENTACJA WSTĘPNYCH WOBEC ZSTEPNYCH}

Nie budzi wątpliwości istnienie szczególnej odpowiedzialności starszego pokolenia za zaspokajanie potrzeb młodszego, które nie jest w stanie utrzymywać się samodzielnie. W tym zakresie naturalne i oczywiste jest pierwszeństwo obowiązku rodziców ponoszenia kosztów związanych z dorastaniem i rozwojem ich dziecka w aspekcie fizycznym, duchowym i intelektualnym ${ }^{17}$. Alimentacja $\mathrm{w}$ istotny sposób wiąże się $\mathrm{z}$ przysługująca rodzicom władzą rodzicielską obejmująca pieczę nad osobą dziecka (art. 96 k.r.o.) ${ }^{18}$. Zadaniem

15 T. Smyczyński, Obowiazek alimentacyjny rodziców względem dziecka a polityka socjalna państwa, Wrocław 1970, s. 33 i n.; T. Smyczyński, w: idem (red.), op. cit., t. 12, s. 765-766; J. Pietrzykowski, w: K. Pietrzykowski (red.), Kodeks rodzinny i opiekuńczy. Komentarz, Warszawa 2012, s. 1152-1153; M. Andrzejewski, w: H. Dolecki, T. Sokołowski (red.), op. cit., s. 745. T. Sokołowski, uzależniając kolejność obowiązku alimentacyjnego od konkretnej sytuacji rodzinnej, umieścił ojczyma i pasierba albo w miejscu rodzica i dziecka, albo na ostatnim miejscu po rodzeństwie uprawnionego (idem, Prawo rodzinne. Zarys wyktadu, Poznań 2010, s. 193). Za subsydiarnym charakterem alimentacji między ojczymem/macochą a pasierbem/pasierbicą opowiedział się J. Gwiazdomorski, w: J. S. Piątkowski (red.), System prawa rodzinnego i opiekuńczego, Wrocław-Warszawa-Kraków-Gdańsk-Łódź 1985, s. 1007-1008.

${ }^{16}$ M. Andrzejewski, w: H. Dolecki, T. Sokołowski (red.), op. cit., s. 745.

${ }^{17}$ Por. uchwała SN z 6 lutego 1969 r., III CZP 129/68, OSN 1969, nr 10, poz. 170. „Zgodnie z utrwalonym poglądem obowiązek dostarczania środków utrzymania i wychowania należy rozumieć szeroko, w tym znaczeniu mianowicie, że rodzice obowiązani są dostarczać małoletnim dzieciom nie tylko tego wszystkiego, co jest potrzebne do ich prawidłowego rozwoju fizycznego i duchowego, ale także sa obowiązani pokryć te wszystkie wydatki, jakie m.in. wynikną czy to w związku z zarządem majątkiem dziecka (jeżeli majątek ten nie wystarcza na te cele), czy ze względu na konieczność prowadzenia spraw, jakie dotyczą osoby dziecka".

18 J. Pietrzykowski, w: K. Pietrzykowski (red.), op. cit., s. 1127. 
rodziców jest bowiem wychowanie dziecka, troska o jego rozwój i przygotowanie do przyszłej pracy. Konstytucja Rzeczypospolitej Polskiej ${ }^{19}$ podkreśla ich pierwszeństwo w tym zakresie, przyznając prawo decydowania, zgodnie $\mathrm{z}$ własnymi przekonaniami, w sprawach związanych z wychowaniem i edukacją ich dziecka (art. 48, art. 53 ust. 3 i art. 70 ust. 3 Konstytucji RP). Trzeba jednak wyraźnie podkreślić, że alimentacja jest niezależna od władzy rodzicielskiej i pełni $\mathrm{w}$ gruncie rzeczy rolę w stosunku do niej służebna ${ }^{20}$. Oznacza to, że obowiązki alimentacyjne ciążą na rodzicach zarówno wówczas, gdy ich władza rodzicielska została zawieszona (art. 110 k.r.o. - np. w związku z wyjazdem za granice w celach zarobkowych), czy ograniczona (art. 109 k.r.o.), jak i w sytuacji, gdy zostali jej pozbawieni (art. 111 k.r.o.), a dziecko umieszczono w którejś z form pieczy zastępczej. Prawa i obowiązki dotyczące sprawowania pieczy nad dzieckiem i jego majątkiem oraz reprezentacji dziecka spoczywaja $\mathrm{w}$ takich sytuacjach na innej osobie, rodzice natomiast nadal mają obowiązek łożyć na jego utrzymanie. $\mathrm{W}$ jego imieniu o świadczenia alimentacyjne maja $\mathrm{w}$ takich przypadkach prawo występować rodzice zastępczy, osoba prowadząca rodzinny dom dziecka albo kierująca placówką opiekuńczo-wychowawczą, regionalną placówką opiekuńczo-terapeutyczną lub interwencyjnym ośrodkiem preadopcyjnym (art. $112^{1}$ k.r.o.), a także kierownik powiatowego centrum pomocy rodzinie po zasięgnięciu opinii koordynatora rodzinnej pieczy zastępczej ${ }^{21}$.

Alimentacja rodziców wobec dziecka niesamodzielnego została w Kodeksie rodzinnym i opiekuńczym uregulowana w wyjątkowy sposób (art. 27 i art. 133 k.r.o. $)^{22}$. Po pierwsze, obejmuje ona nie tylko koszty utrzymania, ale także wychowania małoletniego. Po drugie, przesłanką żądania alimentów nie jest niedostatek, w jakim znaleźć by się miało dziecko, lecz brak możliwości usamodzielnienia się. W tym zakresie prawo nie ogranicza także uprawnienia jedynie do usprawiedliwionych potrzeb dziecka, lecz między rodzicami i ich dziećmi obowiązuje zasada równej stopy życiowej. Trafnie zwrócono w literaturze uwagę, że zasada ta ma szczególne znaczenie w wypadku rodziców o wysokich możliwościach zarobkowych i majątkowych. Potrzeby dzieci powinny być $\mathrm{w}$ takim przypadku zaspokajane na poziomie odpowiadajacym stopie życiowej rodziców, a nie obejmować jedynie potrzeby elementarne ${ }^{23}$. $\mathrm{Z}$ drugiej strony rodzice nie mogą uchylić się od świadczenia alimentów wobec swojego niesamodzielnego dziecka nawet wówczas, gdy powoduje to poważny uszczerbek majatkowy dla nich samych. Maja bowiem w takim wypadku obowiązek dzielić się z dzieckiem nawet najskromniejszymi dochodami ${ }^{24}$, a nawet kosztem substancji ich majątku. Zasada równej stopy życiowej dotyczy wszystkich dzieci zarówno małżeńskich, jak i pozamałżeńskich, niezależnie od

\footnotetext{
19 Konstytucja Rzeczypospolitej Polskiej z 2 kwietnia 1997 r., Dz. U. 1997, Nr 78, poz. 483.

20 T. Smyczyński, w: idem (red.), op. cit., t. 12 , s. 789.

${ }^{21}$ Art. 38 ustawy z 9 czerwca 2011 r. o wspieraniu rodziny i systemie pieczy zastępczej, Dz. U. Nr 149, poz. 887 ze zm.

${ }^{22}$ Szczególna regulacja dotycząca dziecka jest przede wszystkim wyrazem zasady dobra dziecka J. Ignatowicz, M. Nazar, Prawo rodzinne, Warszawa 2010, s. 370.

${ }^{23}$ M. Andrzejewski, w: H. Dolecki, T. Sokołowski (red.), op. cit., s. 735.

${ }^{24}$ Uchwała SN z 9 czerwca 1976 r. Zalecenia kierunkowe w sprawie wzmożenia ochrony rodziny, III CZP 46/75, OSN 1976, nr 9, poz. 184.
} 
tego, czy należą z rodzicami do tej samej wspólnoty domowej ${ }^{25}$. Należy w tym miejscu podkreślić szczególny sposób zaspokajania potrzeb dziecka w przypadku, gdy jego rodzice są małżeństwem. W takiej sytuacji bowiem art. 27 k.r.o. przewiduje obowiązek zaspokajania potrzeb rodziny nałożony na obojga małżonków. Do potrzeb rodziny, o których mowa w przywołanym przepisie, zaliczają się zarówno potrzeby indywidualne każdego jej członka, jak i wspólne potrzeby rodziny, jako grupy ${ }^{26}$. Wśród potrzeb, o których mowa w omawianym przepisie, mieszczą się także koszty utrzymania i wychowania dziecka jednego z małżonków (pasierba) ${ }^{27}$.

Warto jednak zwrócić uwagę, że obowiązek alimentacyjny rodziców względem dziecka nie zawsze będzie musiał być realizowany. Sytuacja taka będzie miała miejsce wówczas, gdy dziecko posiada majątek przynoszący wystarczające dochody (art. 133 k.r.o.). Czysty dochód z majątku dziecka przeznaczany jest bowiem na utrzymanie i wychowanie dziecka oraz jego rodzeństwa, a ewentualna nadwyżka może zostać zużyta na uzasadnione potrzeby rodziny (art. 103 k.r.o.). W takim przypadku, mimo istnienia relacji alimentacyjnej pomiędzy rodzicami a dzieckiem, nie zachodzi przesłanka uzasadniająca świadczenie, polegająca na niemożności zaspokajania swoich potrzeb. Co więcej, w imię solidarności rodzinnej dochody z majątku dziecka mogą służyć także innym członkom rodziny. Należy jednak pamiętać, że zasada ta dotyczy wyłącznie czystego dochodu (przychodu umniejszonego o koszty jego uzyskania), a nie substancji majątku dziecka ${ }^{28}$. Na rodzicach dziecka posiadającego majątek przynoszący odpowiednie dochody nadal ciąży jednak obowiązek podejmowania odpowiednich, osobistych działań w zakresie jego wychowania i wykształcenia ${ }^{29}$. Działanie rodziców będzie obejmowało także decyzje dotyczące sposobu zaspokajania potrzeb dziecka $\mathrm{z}$ dochodów $\mathrm{z}$ jego majątku.

W relacjach pomiędzy rodzicami a niesamodzielnym dzieckiem realizacja obowiązku alimentacyjnego może polegać na osobistych staraniach o jego utrzymanie i wychowanie (art. 27 i 135 § 2 k.r.o.). Ten sposób zaspokajania potrzeb dziecka ma szczególne znaczenie w odniesieniu do dzieci młodszych, wymagających większej troski ze strony dorosłych. W tym miejscu ponownie należy zwrócić uwagę na bliskość pomiędzy osobistymi staraniami dotyczącymi utrzymania i wychowania dziecka oraz władzą rodzicielską. Zaniechanie takich osobistych starań związanych z zaspokajaniem potrzeb dziecka jest uchylaniem się od świadczeń alimentacyjnych i stanowi przykład zaniedbania obowiązków wobec dziecka, które przybierając charakter rażący, mogą stać się podstawa pozbawienia władzy rodzicielskiej (art. 111 k.r.o.). Wydaje się natomiast, że możliwość i obowiązek realizacji świadczenia alimentacyjnego w sposób wskazany w art. $135 \S 2$ k.r.o. w zasadzie ustaja wtedy, gdy dziecko zostało

${ }^{25}$ Uchwała SN z 16 grudnia 1987 r., III CZP 91/86, OSN 1988, nr 4, poz. 42.

${ }^{26}$ T. Smyczyński, w: idem (red.), op. cit., t. 11, s. 213-214.

${ }^{27}$ T. Smyczyński, Obowiazek alimentacyjny..., s. 40.

28 T. Smyczyński, w: idem (red.), op. cit., t. 12 , s. 772.

${ }^{29}$ T. Domińczyk, w: K. Piasecki (red.), Kodeks rodzinny i opiekuńczy. Komentarz, Warszawa 2011, s. 958 . 
umieszczone w pieczy zastępczej. Jeżeli dziecko takie posiada majątek przynoszący dochód pozwalający na jego samodzielne utrzymanie, na rodzicach w tym czasie nie ciąży żaden obowiązek alimentacyjny.

Specjalna ochrona sytuacji materialnej małoletniego dziecka wyklucza także możliwość powołania się przez rodziców na sprzeczność żądania przez nie alimentów z zasadami współżycia społecznego (art. $144^{1}$ zd. 2 k.r.o.). Zatem nawet $\mathrm{w}$ sytuacji nagannego zachowania dziecka czy jego poważnej demoralizacji rodzice nie moga odmówić ponoszenia kosztów jego utrzymania.

Obowiązek alimentacyjny rodziców wobec dziecka nie jest ograniczony uzyskaniem przez nie pełnoletności, lecz możliwością samodzielnego utrzymania się. Uznać jednak należy, że samodzielność taka w zasadzie nie dotyczy dziecka małoletniego ${ }^{30}$, które z definicji, ze względu na początkowy (do 13 roku życia) brak zdolności do czynności prawnych w ogóle i późniejsze (od 13 roku życia) ograniczenie tej zdolności, nie może samo w pełni kształtować swojej sytuacji prawnej. Nawet wówczas gdy dziecko posiada majątek przynoszący dochody wystarczające na jego utrzymanie, rodzice podejmują decyzje dotyczące ich przeznaczenia ${ }^{31}$, realizując zarówno swoje prawo i obowiązek kierowania dzieckiem oraz wychowania go i reprezentując dziecko przy czynnościach, których samo nie może ono dokonać. W tym miejscu ponownie władza rodzicielska styka się z problematyką alimentacji. Małoletnie dziecko, które od strony ekonomicznej mogłoby już być samodzielne, nadal potrzebuje osobistych starań rodziców o zaspokajanie jego potrzeb. Granica samodzielności służy zatem raczej potraktowaniu dziecka pełnoletniego w sposób mniej rygorystyczny, niż w przypadku gdyby pomoc rodziców kończyła się z dniem osiągnięcia pełnoletności. Pozwala to na uzależnienie kontynuacji utrzymania dziecka od jego indywidualnej sytuacji życiowej, na przykład zamiaru dalszej nauki czy trudności w zdobyciu pracy. Może się zdarzyć i tak, że alimentacja dziecka przez rodziców będzie trwała przez całe życie (ich albo dziecka), gdy mimo osiągnięcia pełnoletności nie będzie ono w stanie się usamodzielnić ze względu na chorobę czy niepełnosprawność.

Usamodzielnienie się dziecka powoduje, że traci ono uprzywilejowaną przez prawo alimentacyjne pozycję. Prawo do otrzymywania alimentów nadal przysługuje dziecku, które osiagnęło już samodzielność, ale z różnych powodów znalazło się w sytuacji, która nie pozwala na zaspokojenie jego usprawiedliwionych potrzeb. W takim przypadku jednak przesłanką żądania świadczeń od rodziców będzie niedostatek, w jakim znalazł się dorosły potomek. Należy zatem zwrócić uwagę, że w świetle prawa odpowiedzialność rodziców oraz ciążący na nich obowiązek poczucia solidarności międzypokoleniowej z własnymi dziećmi ulega osłabieniu wraz z osiągnięciem przez dziecko samodzielności i wkrocze-

${ }^{30}$ M. Andrzejewski podkreśla, że „Zdolność dziecka do samodzielnego utrzymania się może nastąpić zarówno przed, jak i po osiągnięciu pełnoletności i to ona, a nie przekroczenie progu pełnoletności, jest kryterium decydującym o wygaśnięciu obowiązku alimentacyjnego rodziców”. Autor zaznacza jednak wcześniej, że dzieci ,z natury nie są w stanie samodzielnie się utrzymać” (idem, Prawo rodzinne..., s. 2018-2019). W literaturze przyjmuje się, że od małoletniego dziecka nie można oczekiwać usamodzielnienia się. J. Pietrzykowski, w: K. Pietrzykowski (red.), op cit., s. 1117.

${ }^{31}$ Rodzice, przeznaczając dochody $\mathrm{z}$ majątku dziecka na zakup konkretnych przedmiotów czy opłacenie rachunków, także zaspokajaja jego potrzeby. 
niem w dorosłe życie. W stosunku do dziecka pełnoletniego rodzice mają bowiem prawo, co do zasady, oczekiwać, że podejmie ono działania w kierunku przejęcia odpowiedzialności za zaspokajanie własnych potrzeb. Mogą oni nawet uchylić się od ponoszenia kosztów utrzymania dziecka, jeżeli wiąże się to z nadmiernym uszczerbkiem dla nich samych lub dziecko nie dokłada starań w celu zapewnienia sobie samodzielności (art. 133 § 3 k.r.o.). W odniesieniu do pełnoletniego dziecka rodzice mogą także powołać się na sprzeczność żądania alimentów z zasadami współżycia społecznego (art. $144^{1}$ k.r.o.) ${ }^{32}$. Przyjęcie takiego rozwiązania uzasadnione jest tym, że rodzicom, $\mathrm{z}$ chwila osiagnięcia przez dziecko pełnoletności, wygasła władza rodzicielska i nie mają oni już wpływu na jego postępowanie ${ }^{33}$.

Obowiązek dostarczania środków utrzymania dziecku, zarówno niesamodzielnemu, jak i usamodzielnionemu, które znalazło się w niedostatku, obciąża oboje rodziców stosownie do ich możliwości zarobkowych i majątkowych. W przypadku gdy zabraknie jednego $\mathrm{z}$ rodziców lub nie może on świadczyć, zobowiązanym, co do całości, jest drugi rodzic. Prawo nie przewiduje bowiem podziału obowiązku alimentacyjnego na linię macierzystą i ojcowską ${ }^{34}$, zgodnie z którym w miejsce nieświadczącego rodzica wchodziliby jego wstępni, czyli dziadkowie uprawnionego. Dopiero gdy żadne z rodziców nie jest w stanie samodzielnie utrzymać dziecka, aktualizuje się obowiązek dalszych krewnych, w pierwszej kolejności wszystkich dziadków ${ }^{35}$. W ich przypadku jednak uzasadnieniem dochodzenia świadczeń będzie niedostatek, w jakim mogłoby znaleźć się dziecko, którego rodzic nie może zaspokoić jego usprawiedliwionych potrzeb $^{36}$.

Należy jednak zwrócić uwagę, że w praktyce dość często to właśnie dziadkowie $\mathrm{w}$ znacznej mierze zaangażowani sa $\mathrm{w}$ pomoc udzielana rodzicom przy sprawowaniu pieczy nad ich dziećmi ${ }^{37}$. Nierzadko osoby, które najpierw

${ }^{32}$ Wprowadzone ustawą z 6 listopada 2008 r. o zmianie ustawy - Kodeks rodzinny i opiekuńczy oraz niektórych innych ustaw (Dz. U. 2008, Nr 220 poz. 1431) przepisy szczególne odpowiadają zasadom słuszności i pozwalają na uniknięcie odwoływania się w tego typu sprawach do art. 5 k.c.

${ }^{33}$ Uzasadnienie rządowego projektu ustawy o zmianie ustawy - Kodeks rodzinny i opiekuńczy oraz niektórych innych ustaw, podane zgodnie z informacją dostępną na: http://orka.sejm.gov.pl/ Druki6ka.nsf/wgdruku/888 (11.04.2012). M. Andrzejewski, w: H. Dolecki, T. Sokołowski (red.), op. cit., s. 755: „Nowy przepis wzmocni pozycję rodzica względem dziecka, które po osiągnięciu pełnoletności, nie podlegając władzy rodzicielskiej, będzie podejmowało nierozsądne decyzje życiowe”.

${ }^{34}$ J. Ignaczewski, w: idem (red.), Alimenty. Sadowe komentarze tematyczne, Warszawa 2009, s. 66.

${ }^{35} \mathrm{Na}$ potrzeby niniejszego opracowania uwagi dotyczące alimentacji dalszych wstępnych na rzecz zstępnych ograniczone zostały do relacji pomiędzy dziadkami a wnukami, dlatego że taka sytuacja najczęściej może występować w praktyce. Rzadziej do świadczenia alimentów na rzecz dziecka zobowiązani będą jego pradziadkowie.

${ }^{36}$ Wyrok SN z 24 maja 1966 r., III CR 89/66, Lex, nr 5992; por. wyrok SN z 16 marca 1967 r., II CR 88/67, OSN 1967, nr 9, poz. 168; J. Gwiazdomorski, w: J. S. Piątowski (red.), op. cit., s. 1015; T. Domińczyk, w: K. Piasecki (red.), op. cit., s. 961.

37 „Sam jednak fakt, że babka dziecka należy do kręgu osób, które mogą być zobowiązane - jako dalsi krewni dziecka - do alimentacji tego dziecka, nie przesądza jeszcze tego, że ciężar zajęcia się dzieckiem spoczywający w pierwszej kolejności na rodzicach dziecka może być przerzucany - w czasie zawodowej pracy osób zobowiązanych do alimentowania dziecka w pierwszej kolejności - na osobę zobowiązaną w dalszej kolejności (wyrok SN z 24 stycznia 1973 r., III CRN 378/72, niepubl.)”. Przytaczam za: J. Ignaczewski (red.), op. cit., s. 67. 
wychowały swoje dzieci, będąc na emeryturze, wychowują i troszczą się o swoje wnuki (np. w związku z wyjazdem dzieci do pracy za granicę), niekiedy kosztem własnej dalszej pracy zarobkowej ${ }^{38}$. Wsparcie takie nie wiąże się z pozostawaniem wnuków w niedostatku czy niemożnością zaspokojenia ich potrzeb przez pracujących rodziców w inny sposób (np. przez zatrudnienie do opieki nad dziećmi osoby trzeciej albo skorzystanie z przedszkola). Wynika ono raczej z ,,potrzeby serca”, z przekonania o znaczeniu budowania więzi rodzinnych pomiędzy starszym a młodszym pokoleniem oraz $\mathrm{z}$ chęci niesienia pomocy i bycia potrzebnym. Zaangażowanie dziadków w opiekę i wychowywanie wnuków, nierzadko połączone $\mathrm{z}$ wykonywaniem niektórych prac domowych, ma także znaczenie ekonomiczne zarówno dla samej rodziny, jak i społeczeństwa. Można jednak równocześnie zauważyć tendencję zachęcania do zwiększania i przedłużania aktywności zawodowej i społecznej seniorów, która ma ich angażować w działalność poza rodziną. Kultura indywidualizmu, samorealizacji, samorozwoju i samowystarczalności ma także swój wpływ na postawy osób starszych, które po przejściu na emeryturę nie zawsze są skłonne udzielać pomocy rodzinie i zajać się wnukami. Wychodzą bowiem z założenia, że to na rodzicach spoczywa obowiązek troski o własne dzieci, a rozmaite dostępne formy zapewnienia dzieciom pieczy przez rodziców pracujących zawodowo (np. przedszkola czy zatrudnienie niani) zwalnia dziadków z konieczności osobistego zaangażowania $\mathrm{w}$ tym zakresie.

Kodeks rodzinny i opiekuńczy nakłada obowiązek alimentacyjny na dziadków, gdy rodziców nie ma albo nie mogą oni samodzielnie zaspokoić potrzeb swojego dziecka i prowadzi to do sytuacji, w której dziecko znajduje się $\mathrm{w}$ niedostatku. W doktrynie przeważa stanowisko, że realizacja obowiązku wobec niesamodzielnego wnuka może, na podstawie art. $135 \S 2$ k.r.o., polegać na osobistych staraniach o utrzymanie i wychowanie dziecka ${ }^{39}$. W takim wypadku, gdy jedno z dziadków realizuje swój obowiązek we wskazany sposób, przyjmując dziecko do swojego gospodarstwa domowego, pozostali dziadkowie zobowiązani będą do pokrywania w całości lub części kosztów utrzymania i wychowania, stosownie do swoich możliwości zarobkowych i majątkowych. Przesłanką alimentacji wobec wnuka jest pozostawanie przez niego w niedostatku, obowiązek świadczenia w konkretnym przypadku może zatem ustać zarówno $\mathrm{w}$ stosunku do małoletniego, jak i pełnoletniego, gdy pojawią się możliwości zaspokajania jego usprawiedliwionych potrzeb z innych źródeł. Dziadkowie mogą także uchylić się od wykonania obowiązku alimentacyjnego, gdy żądanie alimentów przez wnuka jest sprzeczne z zasadami współżycia społecznego. Uprawnienie wynikające z art. $144^{1}$ k.r.o. przysługuje im zarówno w sytuacji, gdy wnuk jest małoletni, jak i pełnoletni.

\footnotetext{
${ }^{38}$ Dziadkowie zamiast swoimi wnukami mogliby odpłatnie opiekować się obcymi dziećmi i uzyskiwać w ten sposób środki utrzymania.

${ }^{39} \mathrm{~W}$ ten sposób J. Pietrzykowski, w: K. Pietrzykowski (red.), op. cit., s. 1127. Inaczej J. Gwiazdomorski, w: J. S. Piątowski (red.), op. cit., s. 1040.
} 


\section{ALIMENTACJA ZSTĘPNYCH WOBEC WSTĘPNYCH}

Obowiązek dostarczania środków utrzymania swoim wstępnym nałożony na zstępnego ma przez dłuższy czas charakter jedynie potencjalny i aktualizuje się dopiero wówczas, gdy dziecko osiagnie samodzielność. Z tego względu w literaturze zwraca się uwagę, że ,,wysunięcie na pierwszy plan obowiązku zstępnych względem wstępnych ma praktycznie niewielkie znaczenie" ${ }^{40}$. Chwila, z którą dziecko staje się samodzielne, ma zatem wpływ zarówno na zakres jego uprawnień alimentacyjnych, jak i na możliwość dochodzenia realizacji jego obowiązków.

Problemowi alimentacji rodziców przez dorosłe dzieci nie poświęca się $\mathrm{w}$ literaturze zbyt wiele uwagi, ograniczając się jedynie do stwierdzenia, że pierwszeństwo obowiązku alimentacyjnego zstępnych przed wstępnymi dotyczy tylko tych osób, które uzyskały już samodzielność życiową ${ }^{41}$. Kolejność wskazana w art. $129 \S 1$ k.r.o. bierze bowiem pod uwagę, że zarabiającym zstępnym łatwiej będzie zaspokoić potrzeby uprawnionego niż jego wstępnym, którzy najczęściej będą osobami w podeszłym wieku, niepodejmujacymi już pracy zarobkowej. O realizacji obowiązku zaspokajania usprawiedliwionych potrzeb rodziców wspomina się także w kontekście art. $135 \S 2$ k.r.o., podając opiekę nad osobą w podeszłym wieku jako przykład osobistych starań o utrzymanie osoby niepełnosprawnej ${ }^{42}$.

Zanim omówione zostaną zasady, na jakich rodzice mogą się domagać środków utrzymania od swych dorosłych dzieci, warto podkreślić, że istotne znaczenie w kontekście budowania solidarności międzypokoleniowej oraz kształtowania poczucia odpowiedzialności za rodzinę ma art. 91 k.r.o., który nakłada pewne obowiązki, zarówno na małoletnie, jak i pełnoletnie dziecko mieszkające $\mathrm{z}$ rodzicami. Przepis ten, jak przyjmuje się $\mathrm{w}$ doktrynie, stanowi konkretyzację obowiązku, wyrażonego $\mathrm{w}$ art. 87 k.r.o., polegającego na udzielaniu sobie wzajemnego wsparcia przez rodziców i dzieci ${ }^{43}$.

Po pierwsze, pozostawanie na utrzymaniu rodziców i mieszkanie z nimi łączy się z obowiązkiem udzielania im pomocy we wspólnym gospodarstwie domowym (art. 91 § 2 k.r.o.). Po drugie, dziecko mieszkające u rodziców, uzyskujące dochody $\mathrm{z}$ własnej pracy, powinno uczestniczyć $\mathrm{w}$ kosztach utrzymania rodziny (art. $91 \S 1$ k.r.o.). Przywołany przepis nie wskazuje wieku dziecka, od którego zależałoby powstanie wymienionych w nim obowiązków, powstają one zatem $\mathrm{z}$ chwila, gdy dziecko staje się zdolne do udzielania pomocy i wraz z dorastaniem moga przybierać coraz poważniejsze formy. Istotne znaczenia ma także moment, gdy dziecko zaczyna uzyskiwać dochody z własnej pracy. W tym zakresie należy pamiętać o regulacji Kodeksu pracy ${ }^{44}$, zgodnie

\footnotetext{
${ }^{40}$ J. Gwiazdomorski, w: J. S. Piątowski (red.), op. cit., s. 1003.

${ }^{41}$ Ibidem; T. Smyczyński, w: idem (red.), op. cit., t. 12, s. 764; J. Ignaczewski, w: idem (red.), op. cit., s. 65 .

42 J. Pietrzykowski, w: K. Pietrzykowski (red.), op. cit., s. 1127.

${ }^{43}$ H. Haak, Wtadza rodzicielska. Komentarz, Torun 1995, s. 28; A. Sylwestrzak, w: H. Dolecki, T. Sokołowski (red.), op. cit., s. 543, H. Ciepła, w: K. Piasecki (red.), Kodeks rodzinny i opiekuńczy. Komentarz, Warszawa 2011, s. 711. Natomiast J. Strzebińczyk uważa, że w art. 87 k.r.o. mowa jest raczej o wsparciu duchowym, a nie materialnym (idem, w: T. Smyczyński (red.), op. cit., t. 12, s. 360-361).

${ }^{44}$ Ustawa z 26 czerwca 1974 r. - Kodeks pracy, Dz. U. 1974, Nr 24, poz. 141 ze zm.
} 
z którym, co do zasady, pracownikiem może być osoba, która ukończyła 18 lat (art. $22 \S 2$ k.p.), zakazane jest natomiast zatrudnianie osób poniżej 16 roku życia (art. $190 \S 2$ k.p. $)^{45}$. Dziecko może także osiagać dochody w związku z pracą wykonywaną na podstawie umów cywilnych ${ }^{46}$, szczególnie umowy zlecenia (art. 734 i n. k.c.) i umowy o dzieło (art. 267 i n. k.c.). Sytuacja ta może dotyczyć zarówno osób pełnoletnich, jak i małoletnich, które ukończyły lat 13 i zawarły stosowną umowę za zgodą swojego przedstawiciela ustawowego (art. 16 i 17 k.c.).

Przesłankami obowiązku z art. $91 \S 1$ k.r.o., polegającego na przyczynianiu się do pokrywania kosztów utrzymania rodziny, są: wspólne zamieszkiwanie $\mathrm{z}$ rodzicami oraz osiąganie dochodów z własnej pracy. Istotne znaczenie maja użyte w tym przepisie słowa: ,jeśli osiąga”. Oznacza to, że nie można oczekiwać od dziecka, szczególnie małoletniego, aby podejmowało pracę zarobkowa ${ }^{47}$. Realizacja obowiązku z art. $91 \S 1$ k.r.o. nie polega zatem na podjęciu takiej pracy, lecz na dzieleniu się zarobkami, jeżeli dziecko takowe osiąga.

Wydaje się, że nieco inaczej traktować należy sytuację dziecka pełnoletniego ${ }^{48}$, wobec którego oczekiwania dotyczące podjęcia pracy sa bardziej uzasadnione, biorąc pod uwagę art. $133 \S 3$ k.r.o. dający rodzicom możliwość uchylenia się od alimentacji, gdy dziecko nie podejmuje starań, aby się usamodzielnić. Pamiętać jednak trzeba, że dziecko, także pełnoletnie, ma prawo zdobyć z pomocą rodziców odpowiednie wykształcenie, które umożliwi mu podjęcie pracy zgodnej z jego zdolnościami (art. 96 § 1 k.r.o.). Mimo to, uznać należy, że obowiązek z art. $91 \S 1$ k.r.o. ulega wzmocnieniu w odniesieniu do zarabiającego już dziecka pełnoletniego. Zgodnie bowiem z zasadą a maiori ad minus, skoro rodzice mają prawo spodziewać się, że dziecko się usamodzielni, tym bardziej maja prawo oczekiwać udziału w kosztach utrzymania, gdy zarabiajace dziecko mieszka $\mathrm{z}$ nimi ${ }^{49}$.

Zgodnie $\mathrm{z}$ art. $91 \S 1$ k.r.o. dziecko ma przyczyniać się do pokrywania kosztów utrzymania rodziny, a zatem - w imię solidarności - dzielić się osiaganymi dochodami. Chodzi więc nie tylko o samodzielne zaspokajanie wyłącznie własnych potrzeb, lecz uczestniczenie we wspólnych kosztach ${ }^{50}$.

${ }^{45}$ Warto zwrócić uwagę, że wiek wskazany w art. 190 § 2 k.p. zostanie obniżony do 15 lat z dniem 1 września 2018 r. na podstawie zmian wprowadzonych w Kodeksie pracy ustawą z 19 marca 2009 r. o zmianie ustawy o systemie oświaty oraz o zmianie niektórych innych ustaw, Dz. U. 2009, Nr 56, poz. 458 .

${ }^{46}$ A. Sylwestrzak, H. Dolecki, T. Sokołowski (red.), op. cit., s. 559.

47 A. Sylwestrzak, Obowiazki dziecka wobec rodziców, „Ruch Prawniczy, Ekonomiczny i Socjologiczny" 2001, z. 3, s. 67.

${ }^{48}$ Konieczność odmiennego traktowania dziecka pełnoletniego i małoletniego zauważa także A. Sylwestrzak, ibidem, s. 68-69.

${ }^{49}$ Podobnie J. Strzebińczyk, T. Smyczyński (red.) op. cit., t. 12, s. 372. W tym kontekście pojawia się pytanie, czy samodzielność jest jednoznaczna z zamieszkaniem osobno i stworzeniem odrębnego gospodarstwa domowego, czy też samodzielne jest także dziecko mieszkające, co prawda, pod jednym dachem ze swoimi rodzicami, ale zaspokajające własne potrzeby z własnych dochodów i uczestniczące we wspólnych kosztach utrzymania. Wydaje się, że także ta druga sytuacja świadczy o samodzielności dziecka. Ma to szczególne znaczenie, biorąc pod uwagę obecną trudną sytuację mieszkaniową.

${ }^{50}$ Zadośćuczynienie obowiązkowi z art. 91 k.r.o. może niekiedy polegać na odciążeniu rodziny od ponoszenia kosztów związanych z zaspokajaniem potrzeb dziecka. A. Sylwestrzak, Obowiazki dziecka wobec rodziców, s. 68 . 
W doktrynie wskazuje się, że omawiane rozwiązanie prawne ma nie tylko znaczenie ekonomiczne dla rodziny, ale przede wszystkim charakter wychowawczy - przygotowuje do dorosłego życia ${ }^{51}$. Ten aspekt odnosi się jednak wyłącznie do dziecka małoletniego, znajdującego się jeszcze pod władzą rodzicielska. Uczestniczenie przez zarabiające dziecko w kosztach utrzymania rodziny to także sposób, w jaki odwzajemnia się ono za to, że mieszka $\mathrm{z}$ rodzicami ${ }^{52}$. W praktyce rodzice nierzadko nie egzekwuja tego obowiązku od swojego dziecka, przyjmując, że póki mogą, sami będą je utrzymywali. W literaturze zwrócono nawet uwagę, że taka postawa rodziców jest prawidłowa i „,nie należy ściągać symbolicznej złotówki ze skromnych dochodów dziecka, gdy pozostali członkowie rodziny osiagaja wysokie dochody" ${ }^{53}$. Podkreślić jednak trzeba, że art. 91 § 1 k.r.o. nie uzależnia ustanowionego w nim obowiązku od niemożności pokrywania kosztów utrzymania rodziny przez pozostałych jej członków ${ }^{54}$. Wskazuje ponadto, że dziecko ma uczestniczyć w zaspokajaniu bieżących potrzeb całej rodziny, a nie tylko swoich. Zatem można przyjąć, że im starsze dziecko i im wyższe osiagane przez nie dochody, tym większy powinien być jego udział w tym zakresie. Wydaje się zatem, że art. $91 \S 1$ k.r.o. pozwala rodzicom oczekiwać, że ich dziecko będzie zaspokajało z otrzymywanych zarobków przynajmniej niektóre własne potrzeby. Za uzasadnione w konkretnym przypadku można uznać jednak i takie rozwiązanie, gdy pełnoletnie dziecko w minimalnym stopniu uczestniczy w kosztach utrzymania siebie i rodziny, oszczędzając tym samym w celu usamodzielnienia się w niedalekiej przyszłości. Jeżeli jednak wspólne zamieszkiwanie z rodzicami ma być stanem permanentnym, rodzice mają prawo oczekiwać większego udziału dziecka we wspólnych wydatkach. Z tego względu wydaje się, że należałoby potraktować obowiązek uczestniczenia w kosztach utrzymania rodziny ciążący na dziecku pełnoletnim zamieszkującym z rodzicami raczej jako obowiązek quasi-alimentacyjny, podobny do obowiązku małżonków $\mathrm{z}$ art. 27 k.r.o. ${ }^{55}$, a nie zobowiązanie niezupełne niegwarantowane przymusem państwowym. Zgodzić należy się ze stanowiskiem o dopuszczalności powództwa rodziców przeciwko „opieszałemu dziecku, niepartycypującemu - mimo posiadanych dochodów z pracy i wspólnego zamieszkiwania $\mathrm{z}$ rodzicami w kosztach utrzymania rodziny" ${ }^{56}$.

Za dopuszczalne uznać należy także zawarcie umowy pomiędzy rodzicami a pełnoletnim dzieckiem, której przedmiotem miałby być sposób realizacji obowiązku przyczyniania się do zaspokajania potrzeb rodziny ${ }^{57}$.

Analizowany przepis art. $91 \S 1$ k.r.o. dotyczy zarobków dziecka uzyskiwanych $\mathrm{z}$ tytułu wykonywanej pracy, istotną rolę odgrywa jednak także

${ }^{51} \mathrm{~W}$ ten sposób także A. Sylwestrzak, ibidem, s. 63.

52 Ibidem.

53 J. Gajda, Kodeks rodzinny i opiekuńczy. Akty stanu cywilnego. Komentarz, Warszawa 2002, s. 373.

${ }^{54}$ H. Haak wskazuje, że samo osiaganie dochodów, czy to z własnej pracy, czy z majątku, stwarza obowiązek wspierania rodziny na podstawie art. 87, 91 i 103 k.r.o. (H. Haak, op. cit., s. 29).

${ }^{55} \mathrm{O}$ podobieństwie i różnicach między art. 27 i 91 § 1 k.r.o. J. Strzebińczyk, w: T. Smyczyński (red.), op. cit., t. 12 , s. $370-372$.

${ }^{56}$ Ibidem, s. 373. J. Strzebińczyk podkreśla jednak, że stanowisko to nie jest aprobowane przez większość doktryny.

${ }^{57}$ A. Sylwestrzak, Obowiazki dziecka wobec rodziców, s. 68-69. 
art. 103 k.r.o., który pozwala przeznaczyć nadwyżkę czystego dochodu z majątku dziecka na uzasadnione potrzeby rodziny ${ }^{58}$.

$\mathrm{W}$ art. $91 \S 2$ k.r.o. przewidziano jeszcze jeden obowiązek dziecka względem rodziców, polegający na udzielaniu pomocy we wspólnym gospodarstwie domowym. Dotyczy on dzieci, które pozostaja na utrzymaniu rodziców i mieszkaja z nimi. Jak już wspomniano, ustawodawca nie wskazuje granicy wieku, od której można oczekiwać realnego zaangażowania dziecka w sprawy związane ze wspólnym domem. Rodzice powinni zatem określić, w jaki sposób dziecko będzie czynić zadość swoim obowiązkom, uwzględniając konkretną sytuację rodzinną, wiek oraz dojrzałość dziecka. Podkreślić należy, że regulacja przewidziana w art. $91 \S 2$ k.r.o. zdecydowanie częściej znajduje zastosowanie, niż ta z art. $91 \S 1$ k.r.o., dotyczy bowiem każdego dziecka, i to niezależnie od jego wieku.

Niewykonywanie obowiązków z art. 91 k.r.o. nie jest obwarowane żadna szczególną sankcją, w doktrynie zwraca się jednak uwagę, że pewne negatywne konsekwencje moga wynikać z zastosowania dostępnych regulacji prawnych. Po pierwsze, wskazuje się na art. 21 k.c., zgodnie z którym sąd może wydać postanowienie o przeznaczeniu zarobków osoby ograniczonej w zdolności do czynności prawnych, o ile przemawiaja za tym ważne powody ${ }^{59}$. Pamiętać bowiem należy, że zarobki małoletniego dziecka na podstawie art. $101 \S 2$ sa wyłączone z zarządu sprawowanego przez rodziców.

Drugim proponowanym środkiem prawnym, który może znaleźć zastosowanie w przypadku, gdy dziecko nie realizuje obowiązków wynikających z art. 91 k.r.o., jest art. 100 k.r.o. ${ }^{60}$ Przepis ten przyznaje rodzicom prawo domagania się pomocy od sądu i innych organów publicznych, gdy jest ona potrzebna do należytego wykonywania władzy rodzicielskiej. Można mieć jednak watpliwości, czy wymuszenie realizacji obowiązku przyczyniania się przez dziecko do zaspokajania potrzeb rodziny i pomocy $\mathrm{w}$ gospodarstwie domowym łączy się z władzą rodzicielską, skoro jest od niej niezależny ${ }^{61}$.

Trzecim sugerowanym rozwiązaniem jest skorzystanie $\mathrm{z}$ art. 109 k.r.o., gdyż „lekceważenie przez dziecko jego obowiązków może stanowić zagrożenie jego dobra" ${ }^{62}$. W tym przypadku sąd mógłby na przykład zobowiązać dziecko do określonego zachowania na podstawie art. $109 \S 2$ pkt 1 k.r.o.

Należy jednak w tym miejscu zwrócić uwagę, że wszystkie wymienione środki dotyczą sytuacji dziecka małoletniego, nad którym sprawowana jest władza rodzicielska. Pojawia się zatem pytanie, co w sytuacji, gdy swoich obowiązków wobec rodziców (określonych w art. 91 k.r.o.) nie wykonuje osoba

${ }^{58}$ H. Haak podkreśla, że ten przepis również stanowi konkretyzację obowiązku wspierania rodziców przewidzianego w art. 87 k.r.o. (idem, op. cit., s. 114).

${ }^{59}$ H. Ciepła, w: K. Piasecki (red.), op. cit., s. 726.

60 Ibidem.

${ }^{61}$ Obowiązek udziału dziecka w zaspokajaniu potrzeb rodziny należy do stosunków niezależnych od władzy rodzicielskiej. Zob. J. Strzebińczyk, w: T. Smyczyński (red.), op. cit., t. 12, s. 358 i n. Podobnie J. Ignatowicz, w: J. S. Piątowski (red.), op. cit., s. 788; J. Ignatowicz, w: K. Pietrzykowski (red.), op. cit., s. 860 .

${ }^{62}$ H. Haak, op. cit., s. 31. 
pełnoletnia, która - co prawda - częściowo sama zaspokaja swoje potrzeby, ale nie uczestniczy, chociażby mogła, w kosztach utrzymania rodziny, mimo że z nią mieszka (np. pełnoletni syn, który już zarabia, ale nie ma możliwości zakupu mieszkania ze względu na brak zdolności kredytowej). Rodzice mogą uchylić się $\mathrm{w}$ takiej sytuacji od świadczenia alimentów na podstawie art. $133 \S 3$ k.r.o. albo żądać ich zmniejszenia na podstawia art. 138 k.r.o. Zgodnie z przeważającym stanowiskiem doktryny, nie przysługuje im jednak żaden środek polegający na egzekucji obowiązku z art. $91 \S 1$ k.r.o. ${ }^{63}$ Dostępnymi sankcjami, które wskazuje się w doktrynie, sa wówczas na przykład wydziedziczenie na podstawie art. 1008 pkt 3 k.c. czy odwołanie darowizny (art. $898 \S 1$ k.c.) ${ }^{64}$. Przyznanie rodzicom jedynie pośrednich i odłożonych w czasie środków oddziaływania na mieszkające $\mathrm{z}$ nimi pełnoletnie i zarabiające dziecko nie wydaje się jednak słuszne, dlatego należałoby rozważyć dopuszczalność stosownego powództwa $\mathrm{z}$ ich strony.

W kontekście tematu niniejszego opracowania trzeba jednak wyraźnie podkreślić, że większość doktryny opowiada się za tym, że obowiązek dziecka polegający na przyczynianiu się do ponoszenia kosztów utrzymania rodziny uregulowany w art. $91 \S 1$ k.r.o. nie ma charakteru alimentacyjnego ${ }^{65}$.

Dostarczanie środków utrzymania rodzicom przez samodzielne już dzieci podlega ogólnym zasadom regulującym alimentację pomiędzy krewnymi w linii prostej. Pierwsza przesłanka jest zatem istnienie stosunku pokrewieństwa, druga - pozostawanie rodziców w niedostatku.

Obserwacja pewnych przemian społecznych, jakie dokonały się w ostatnich dekadach, prowadzi do wniosku, że mają one istotny wpływ także na regulację prawa alimentacyjnego ${ }^{66}$. Prawo rodzinne dawno odeszło od modelu rodziny wielopokoleniowej, która wspólnie zaspokajała swoje potrzeby, łącząc pod jednym dachem dziadków, rodziców i dzieci. Kodeks rodzinny i opiekuńczy zdecydowanie koncentruje się na stosunkach prawnych łączących członków tak zwanej rodziny nuklearnej, czyli rodziców i ich małoletnie dzieci ${ }^{67}$. W praktyce jednak nierzadko rodzina udziela sobie nieformalnego wsparcia w zdecydowanie szerszym zakresie, niż przewiduje prawo rodzinne, realizując postulaty solidarności międzypokoleniowej. Przykładem może być nienależące do

${ }^{63}$ Zob. przyp. 56.

${ }^{64}$ A. Sylwestrzak wymienia te środki w odniesieniu do art. 87 k.r.o., art. 91 k.r.o. jest jednak konkretyzacją, zatem można je uznać za odpowiednie i w tym przypadku (idem, w: H. Dolecki, T. Sokołowski (red.), op. cit., s. 543). Przepisy o wydziedziczeniu i odwołaniu darowizny moga zostać zastosowane także wobec dziecka małoletniego.

${ }^{65}$ W ten sposób J. Ignatowicz, w: J. S. Piątowski (red.), op. cit., s. 788; J. Ignatowicz, w: K. Pietrzykowski (red.), op. cit., s. 860; K. Gromek, Kodeks rodzinny i opiekuńczy. Komentarz, Warszawa 2009, s. 1380; A. Sylwestrzak, w: H. Dolecki, T. Sokołowski (red.), op. cit., s. 557. Szerzej na temat różnic pomiędzy obowiązkiem alimentacyjnym a obowiązkiem z art. 91 k.r.o.: A. Sylwestrzak, Obowiazki dziecka wobec rodziców, s. 61 i n. Inaczej H. Haak, op. cit., s. 28; autor uważa obowiązki z art. 91 k.r.o. za obowiązki alimentacyjne, mające szerszy zakres niż art. 128 k.r.o., przy czym ten szerszy zakres nie podlega sankcji za naruszenie.

${ }^{66}$ Przemiany społeczne były impulsem do nowelizacji prawa alimentacyjnego w $2008 \mathrm{r}$. Zob. Uzasadnienie rządowego projektu ustawy o zmianie ustawy - Kodeks rodzinny i opiekuńczy oraz niektórych innych ustaw, dostępne na: http://orka.sejm.gov.pl/Druki6ka.nsf/wgdruku/888 (11.04.2012).

67 T. Smyczyński, Prawo rodzinne i opiekuńcze, Warszawa 2009, s. 5. 
obowiązków alimentacyjnych ${ }^{68}$ wyposażenie przez rodziców dzieci wchodzących w dorosłe życie ${ }^{69}$ (np. zakup i remont mieszkania czy zakup samochodu), a także pomoc dziadków przy sprawowaniu pieczy nad małoletnimi wnukami, umożliwiająca obojgu rodzicom podjęcie pracy zawodowej. Zaangażowanie starszego pokolenia $\mathrm{w}$ zabezpieczenie przyszłości oraz udzielanie wsparcia młodszemu jawi się jako naturalne i oczekiwane. Należy jednak przyjrzeć się również problematyce pomocy świadczonej przez rodzinę osobom w podeszłym wieku, które z tego względu tracą możliwość samodzielnego zaspokajania swoich potrzeb i także powinny znaleźć się pod szczególną ochroną prawa. Srodkiem, który z założenia miał stanowić gwarancję finansową na przyszłość, miał być system zabezpieczenia społecznego, w ramach którego osoba pracująca przez całe swoje zawodowe życie gromadzi środki na przyszłą emeryturę. System ten $\mathrm{w}$ pewien sposób zwolnił rodzinę $\mathrm{z}$ odpowiedzialności za osoby starsze $^{70}$. W przeciwieństwie do świadczeń ze strony państwa na rzecz małoletnich dzieci, które maja charakter pomocniczy, świadczenia należne z tytułu wypracowanej przez osobę dorosła emerytury maja pierwszoplanowe znaczenie dla możliwości samodzielnego zaspokajania swoich potrzeb. Zastępują one bowiem utracone dochody z pracy i są efektem aktywnego życia zawodowego. Zaspokojenie potrzeb życiowych powinno nastąpić z własnych środków ${ }^{71} \mathrm{i}$ z tego względu prawo do emerytury wyprzedza możliwość dochodzenia alimentów, które mają charakter uzupełniajacy ${ }^{72}$. Wydłużenie się ludzkiego życia, spadek dzietności oraz zwiększona mobilność osób w wieku produkcyjnym stawiaja jednak ten problem w zupełnie nowym świetle. Wszystkie wskazane zjawiska maja bowiem wpływ na kwestię zagwarantowania wypłacalności państwa w stosunku do osób nabywających uprawnienia emerytalne. W tym kontekście regulacja prawa alimentacyjnego może nabrać szczególnego znaczenia.

Analizując prawo alimentacyjne w kontekście uprawnień osób w podeszłym wieku, należy zwrócić uwagę na brak społecznej świadomości istnienia regulacji prawnej przewidującej możliwość domagania się przez takie osoby wsparcia ze strony członków najbliższej rodziny. Dostarczanie środków utrzymania kojarzy się bowiem z relacją pomiędzy rodzicami a ich niesamodzielnymi dziećmi oraz między małżonkami i jest najczęściej odnoszona do sytuacji po rozwodzie. Osoby starsze pozostające $\mathrm{w}$ niedostatku nie zgłaszaja roszczeń alimentacyjnych przeciwko swoim bliskim (najczęściej dzieciom), gdyż nie wiedzą o istnieniu po ich stronie stosownego uprawnienia albo nie chca obciążać najbliższych dodatkowymi wydatkami. Istotna przyczyną rezygnacji z dochodzenia świadczeń sa zatem także względy psychologiczne oraz emocjonalne. Osoby zobowiązane do dostarczania środków utrzymania swoim rodzicom czy dziadkom również nierzadko pozostają $\mathrm{w}$ nieświadomości, uznając, że obowiązek odpowiednich

\footnotetext{
68 J. Pietrzykowski, w: K. Pietrzykowski (red.), op. cit., s. 1086.

69 J. Gwiazdomorski, w: J. S. Piątowski (red.), op. cit., s. 1039.

70 T. Smyczyński, w: idem (red.), op. cit., t. 12 , s. 754 .

${ }^{71}$ Uchwała SN z 16 grudnia 1987 r., III CZP 91/86, OSN 1988, nr 4, poz. 42.

72 T. Smyczyński, Alimentacja członków rodziny..., s. 199-200.
} 
świadczeń osobom starszym ciąży na państwie ${ }^{73}$. Zaznaczyć należy, że w wielu rodzinach osobista oraz finansowa pomoc udzielana osobom starszym realizowana jest jako coś oczywistego, wynikającego $\mathrm{z}$ obowiązku moralnego, a niekiedy w poczuciu wdzięczności za wcześniejsze wsparcie rodziców. Tymczasem także w tym względzie norma moralna znajduje swoje wzmocnienie w odpowiedniej normie prawnej. Podkreślić należy, że ma to istotne znaczenie w czasach, gdy więzi rodzinne między dorosłymi dziećmi a ich rodzicami ulegaja niekiedy istotnemu osłabieniu, co w pewnym stopniu wynika $\mathrm{z}$ promowanej kultury indywidualizmu.

Warto także zwrócić uwagę, że stosunki alimentacyjne mają charakter wzajemny ${ }^{74}$, chociaż traktuje się je jako niezależne od siebie i nie stanowią one spłaty wcześniejszych świadczeń ze strony krewnych. Prawo odwołuje się jednak w tej kwestii do zasad słuszności, dając możliwości uchylenia się od wykonania obowiązku alimentacyjnego, gdy żądanie alimentów jest sprzeczne z zasadami współżycia społecznego (art. $144^{1}$ k.r.o.). Dotyczyć to może na przykład sytuacji, gdy alimentów od dorosłego dziecka domaga się rodzic, który został pozbawiony władzy rodzicielskiej, nie interesował się dzieckiem i sam nie łożył na jego utrzymanie.

Jak zatem wygląda regulacja prawna dotycząca obowiązków dostarczania środków utrzymania wstępnym, którzy nie moga samodzielnie zaspokajać swoich potrzeb. Zgodnie z art. 129 k.r.o. zobowiązanymi w pierwszej kolejności do alimentowania osób, które znalazły się w niedostatku, są ich samodzielni zstępni. Zstępni bliżsi stopniem pokrewieństwa wyprzedzają dalszych (a zatem dzieci uprawnionego ponoszą odpowiedzialność przed jego wnukami). Zstępni $\mathrm{w}$ tym samym stopniu spokrewnieni $\mathrm{z}$ uprawnionym nie sa zobowiazani solidarnie, lecz wysokość ich świadczenia uzależniona jest od możliwości zarobkowych i majątkowych każdego $\mathrm{z}$ nich (art. 129 § 2 k.r.o.). Każde z kilkorga dzieci obciążone jest zatem stosownie do swoich możliwości, a określając wysokość świadczeń, należy brać pod uwagę nie tylko rzeczywiście osiagane dochody i posiadany majątek, ale także wykształcenie, sytuację życiowa, zdrowotna, rodzinną oraz rynek pracy.

Przesłanką alimentacji w przypadku rodziców dochodzących świadczeń od swoich dzieci jest pozostawanie przez nich w niedostatku. Pojęcie to nie jest jednak $\mathrm{w}$ żaden sposób doprecyzowane, a w doktrynie pojawiają się pewne rozbieżności. Przyjmuje się, że „niedostatek” to sytuacja, w której osoba nie jest w stanie zaspokoić samodzielnie swoich usprawiedliwionych potrzeb, mimo podejmowania starań $w$ tym zakresie ${ }^{75}$. Jednocześnie jednak można zauważyć trudności w określeniu, czym są owe usprawiedliwione potrzeby. Z jednej strony znaleźć można w tym kontekście odwołania do takich pojęć, jak „,minimum

${ }^{73} \mathrm{Na}$ znikomą liczbę spraw o alimenty wszczynanych przez osoby starsze zwrócił uwage T. Smyczyński (idem, Alimentacja członków rodziny..., s. 201). Uznać należy, że mimo upływu czasu od ukazania się przywołanej publikacji, sytuacja faktyczna nie uległa zmianie. W związku z rozwojem gospodarczym zauważyć jednak można pojawienie się niekiedy istotnych różnic w poziomie życia dziadków, rodziców i dzieci.

${ }^{74}$ T. Smyczyński, w: idem (red.), op. cit., t. 12, s. 758.

75 J. Gwiazdomorski, w: J. S. Piątowski (red.), op. cit., s. 1016. 
socjalne”76 czy „bieda absolutna”, rozumiana jako „,brak możliwości zaspokojenia podstawowych potrzeb człowieka: żywnościowych, mieszkaniowych i zdrowotnych" ${ }^{77}$. Z drugiej zwraca się uwagę, że potrzeby usprawiedliwione to nie to samo, co potrzeby niezbędne, lecz stanowią one pojęcie szersze, a oceniając charakter potrzeb, należy brać pod uwagę takie okoliczności, jak wiek, stan zdrowia, sytuacja zawodowa i status społeczny uprawnionego ${ }^{78}$. Zaspokajanie usprawiedliwionych potrzeb wykracza zatem poza zapewnienie elementarnego minimum egzystencji i polega na ,stworzeniu uprawnionemu normalnych warunków bytowania, odpowiadających jego wiekowi, stanowi zdrowia i innym okolicznościom konkretnej sprawy, jeżeli uprawniony nie może zaspokoić swych potrzeb własnymi siłami" ${ }^{79}$.

Użyte w art. $133 \S 2$ k.r.o. określenie niedostatek mogłoby sugerować konieczność odwołania się do jakichś kryteriów obiektywnych przy ustalaniu zarówno istnienia uprawnienia, jak i zakresu świadczeń alimentacyjnych. Uzależnienie jednak wysokości świadczenia od usprawiedliwionych potrzeb uprawnionego oraz możliwości zarobkowych i majątkowych zobowiązanego (art. $135 \S 1$ k.r.o.) wskazuje, że należy brać pod uwagę konkretną sytuację rodzinną. W tym kontekście zaspokojenie wyłącznie potrzeb niezbędnych do życia może okazać się zbyt wąskie w stosunku do usprawiedliwionych potrzeb uprawnionego. Ustalając wysokość alimentów, należy także wziąć pod uwagę stopień pokrewieństwa łączący strony stosunku alimentacyjnego, przyjmując, że im bliższe pokrewieństwo, tym więcej potrzeb można uznać za usprawiedliwione. Pomocne może okazać się także porównanie stopy życiowej uprawnionego i zobowiązanego i dążenie do tego, aby nie było między nimi rażącej dysproporcji. Zbliżenie poziomu życia ma szczególne znaczenie $\mathrm{w}$ odniesieniu do alimentacji między krewnymi w linii prostej ${ }^{80}$. Wydaje się, że przy ustalaniu wysokości świadczenia należałoby także brać pod uwagę, czy osoba uprawniona w przeszłości świadczyła nieodpłatnie pomoc w sprawowaniu pieczy i wychowaniu wnuków oraz w prowadzeniu gospodarstwa domowego swoich dorosłych dzieci. W takiej sytuacji szerszy zakres usprawiedliwionych potrzeb uzasadniony byłby tym, że gdyby uprawniony w tym okresie świadczył odpłatnie podobne usługi osobom trzecim lub podjął inne zatrudnienie, zwiększyłby na przyszłość możliwość samodzielnego ponoszenia kosztów swojego utrzymania. Oczywiście można przyjąć, że zgodnie z zasadą volenti non fit iniuria, skoro dziadkowie dobrowolnie udzielali pomocy swoim dzieciom i wnukom, nie powinni oczekiwać w przyszłości zwrotu świadczenia z ich strony. W gruncie rzeczy jednak mogliby oni domagać się regresu na podstawie art. 140 k.r.o. Uznać należy, że w sytuacji, gdy rodzice/dziadkowie, którzy pomagali wcześniej swoim dzieciom/wnukom, nie moga zaspokoić swoich uzasadnionych potrzeb, zastosowanie powinny znaleźć zasady słuszności,

76 T. Smyczyński, Obowiazek..., s. 698-701; idem, Alimentacja członków rodziny..., s. 24 i n.

77 T. Smyczyński, w: idem (red.), op. cit., t. 12, s. 770.

${ }^{78}$ J. Gwiazdomorski, w: J. S. Piątowski (red.), op. cit., s. 1016; T. Smyczyński, Obowiazek..., s. 41.

79 J. Pietrzykowski, w: K. Pietrzykowski (red.), op. cit., s. 1125.

${ }^{80}$ J. Gwiazdomorski, w: J. S. Piątowski (red.), op. cit., s. 1043-1044. 
które w braku poczucia obowiązku moralnego po stronie osób korzystających z udzielonej pomocy, powinny przy orzekaniu alimentów wpłynąć na relację między członkami rodziny.

Analizując z kolei możliwości zarobkowe i majątkowe zobowiązanego zstępnego, należy - poza wskazanymi już aspektami dotyczącymi możliwości zawodowych i majątkowych - brać pod uwagę, czy ma on na utrzymaniu swoje niesamodzielne dzieci. Oczywiste jest bowiem pierwszeństwo odpowiedzialności rodziców za utrzymanie swoich dzieci, gdy ich jednak nie ma, większym obowiązkiem można obciążyć samodzielne dzieci wobec rodziców (czy dziadków) w podeszłym wieku.

Realizacja obowiązku alimentacyjnego wobec rodziców może polegać na dostarczaniu środków utrzymania w pieniądzu lub naturze, zobowiązany może także podjać osobiste starania w celu zaspokojenia potrzeb życiowych uprawnionego, gdy jest nim osoba niepełnosprawna. Ten drugi sposób dotyczy sytuacji, gdy rodzice lub dziadkowie, ze względu na stan zdrowia lub wiek, nie moga już samodzielnie zaspokajać swoich potrzeb, mimo otrzymywanych środków (np. nie moga mieszkać sami). Wówczas obowiązek alimentacyjny może być zaspokajany poprzez wspólne zamieszkanie z rodzicami i codzienną o nich troskę.

Jak już wspomniano, uregulowana prawnie alimentacja wobec wstępnych nie jest w świadomości społecznej tak oczywista, jak alimentacja rodziców wobec dzieci. Dlatego za istotne należałoby uznać propagowanie wiedzy na ten temat.

\section{PODSUMOWANIE}

Podsumowując analizę regulacji prawa alimentacyjnego, należy podkreślić, że stanowi ona wyraz świadomości istnienia solidarności międzypokoleniowej pomiędzy członkami rodziny. Jak podkreślono w opracowaniu, dostarczanie środków utrzymania swoim najbliższym ma mocne uzasadnienie moralne, wzmocnione jedynie przepisami prawa ${ }^{81}$. Zaspokajanie potrzeb rodziny, także rodziny wielopokoleniowej, dla większości rodzin jawi się jako oczywiste i wykonywane jest bez szczególnej świadomości realizowania obowiązku prawnego. Przepisy prawa określaja jednak pewne minimum tego, co krewni powinni sobie zapewnić we wzajemnych relacjach. Warto jednak zaznaczyć, że prawo alimentacyjne przewiduje pewne granice ponoszenia odpowiedzialności związanej z zaspokajaniem potrzeb najbliższych. Po pierwsze, przepisy wskazują sposób określenia zakresu świadczeń alimentacyjnych, podkreślając, że domagać się można jedynie tego, co służy zaspokojeniu potrzeb usprawiedliwionych. Po drugie, dostarczanie środków utrzymania uprawnionemu nie ma prowadzić do niedostatku po stronie zobowiązanego. $\mathrm{Z}$ tego względu pod uwagę bierze się także jego możliwości zarobkowe i majątkowe, aby udzielana pomoc była wyrazem solidarności rodzinnej, dzieleniem się tym, co się posiada. Niekiedy

\footnotetext{
${ }^{81}$ T. Smyczyński, w: idem (red.), op. cit., t. 12, s. 754.
} 
sytuacja materialna zobowiązanego uniemożliwia mu realizację obowiązku, aktualizuje się wówczas obowiązek kolejnej osoby. Po trzecie, prawo alimentacyjne pozwala na uchylenie się od świadczeń alimentacyjnych, gdy żądanie alimentów jest sprzeczne z zasadami współżycia społecznego. Nie chodzi bowiem o to, żeby obciążać kosztami utrzymania krewnych osoby, która sama swoim postępowaniem wpędziła się w niedostatek i nie daje gwarancji, że udzielona pomoc okaże się skuteczna ${ }^{82}$.

Biorąc pod uwagę obecną sytuację demograficzna, należy uznać, że w przyszłości w istotny sposób wzrosnąć może znaczenie regulacji uprawnień osób starszych wobec młodszych członków ich rodzin. Kolejne pokolenie znaleźć może się $\mathrm{w}$ związku z tym $\mathrm{w}$ trudnej sytuacji, ponosząc zarówno publiczne koszty związane ze stanowiącym wyraz solidarności międzypokoleniowej systemem zabezpieczenia społecznego, jak i prywatne koszty utrzymania swoich najbliższych, zarówno zstępnych, jak i wstępnych.

dr Matgorzata Łaczkowska

Uniwersytet im. Adama Mickiewicza w Poznaniu

\section{MAINTENANCE LAW AS AN EXAMPLE OF A LEGAL REGULATION PERTAINING TO INTERGENERATIONAL SOLIDARITY}

\section{Summary}

The year 2012 was announced the Year for Active Ageing and Solidarity between Generations in Decision No 940/2011/EU of the European Parliament and the European Council.

The paper features the issue of Polish maintenance law which is an example of a legal regulation of the solidarity between generations. Basically, the support given and received by family members has very strong moral roots. The legal regulation provides for minimal protection only, which may be executed using the power of the state.

The solidarity between generations, effected by the provision of the means for living, is very obvious in the relations between parents and children, especially when the beneficiary is an underage child (a minor). However, the right to claim maintenance is also guaranteed by law to parents (and grandparents). When an elderly person is not able to support herself or himself, the law gives them an opportunity to turn to descendents for help. It should be emphasised that this aspect of maintenance which has, so far, been a very rare subject of analyses, is gradually becoming more important from the perspective of the existing demographic problems and the process of ageing in our society.

${ }^{82}$ Uchwała SN z 16 grudnia 1987 r., III CZP 91/86, OSN 1988, nr 4, poz. 42; J. Pietrzykowski, w: K. Pietrzykowski (red.), op. cit., s. 1120. 